\author{
Adam Skreczko* \\ Cardinal Stefan Wyszyński University in Warsaw, Poland
}

\title{
Parent Pedagogization as the Need of the United Europe
}

\section{Introduction}

The parents' ability to bring up children properly is achieved by their constant enrichment with new knowledge. Parents need both help from the outside and proper recommendations on how to bring up children to fulfill their parental duties. After all, parents are the ones who carry the responsibility for bringing up children, and the lack of the adequate training in the upbringing process may cause serious damage in the child's later life. The educational work of the parents (family) starts a process which should then be supported (but not taken over) by the school and fostered by environmental influences, as well as by the self-activity of the child himself. It is thanks to the educational function (vocation) of the family that the child is prepared to perform social functions, both within and outside the family structure.

The need of pedagogization also derives from the fact that today's social and cultural reality creates difficult conditions for the process of adaptation, and hence it requires additional educational instructions and abilities of the parents.

* ADAM SKRECZKO - priest of the Archdiocese of Bialystok, professor of theology. Head of the Chair of Pastoral Theology of Marriage and Family at the Faculty of Family Studies at Cardinal Stefan Wyszynski University in Warsaw. Author of numerous publications on pastoral theology and pedagogy, especially in the field of upbringing in the family. 
In this paper, I would like to pay special attention to the need of constant parent pedagogization, derived from the sense of responsibility of bringing up children. Permanent enrichment of the parents' pedagogical consciousness results in an increased and improved quality of their influence upon their children and it constitutes a chance for new education, so important for the new shape of Europe. I intend to achieve this by focusing on the following issues: First, presenting the family as the primary educating environment, secondly, showing the need and the ways of parent pedagogization with regard to raising children, and finally, establishing what the challenge of being a parent requires from them.

\section{Family as the First Educating Community}

Throughout the history of mankind, from the ancient times through the Middle Ages until present time, the rights of the parents to bring up their children have not been questioned. The parents were the first educators of their children and their authority was respected, which is best expressed in the morally-religious commandment: "Honor your father and your mother" (Exodus 20,12) given to the people in the second millenium BC.

A family welcomes the child on the threshold of his existence, and it accompanies him throughout his whole life. The "psychological core" of one's personality is formed as early as the prekindergarten period, and it is shaped mainly by the family. Expressing my opinion on the Participation of the Parents in Educating Children I wish to note first, that there are other circles which take part in bringing up children in an auxiliary way but the family should always be put in the first place in this difficult and complex process. This fact is recognized by both secular and ecclesiastical environments.

On December 10 1948, the United Nations adopted The Common Declaration of Human Rights where we read: "The family is a natural and basic social cell and it has the right to protection from the society and the state" (article 16 point 3 ). "Mother and child have the right to special care and help" (article 25 point 2), and "Parents have the priority in choosing the education that will be given to their children"1 (article 26 point 3 ). In other words: the parents have the right to choose a school which would suit their children's needs. In The Declaration of the Rights of

1 The UN General Assembly, Common Declaration of Human Rights, in: J. Machowski, Work of Man, Warsaw 1968, p. 191-197. 
the Child, adopted by the UN on 20 November 1959, it is emphasized that a child "should grow under the protection and responsibility of the parents" (principle 6). In the process of educating and upbringing, as the Declaration says, all "people responsible for the upbringing and the management of the child should bear in mind his welfare; this responsibility lies mainly with the parents" (principle 7) ${ }^{2}$. So in the light of the resolutions of the UN General Assembly, which became international law in force, the primary right to bring up children belongs to the family. Once more the UN emphasized, on 16 December 1966, when the General Assembly adopted The International Pact of Civic and Political Rights ${ }^{3}$, that "every child - notwithstanding his race, color of the skin, sex, religion, ethnic and social background, wealth or birth - has the right to the protective measures required by the status of a minor from family and society" (article 24 point 1 ). This time, again, the priority in the protection and education of the child was assigned to the family, then to the nation and only then to the state. Unfortunately, in totalitarian states, the right of the parent to raising children was, and still is, on paper only, and has been usurped by these political systems.

No wonder, that the assembly of Catholic bishops from all over the world at the Vatican Council II reminded the politicians and the states of the resolutions in force adopted by the UN: "Parents, as they have given life to children, are obliged to the highest degree to raise offspring and therefore they have to be recognized as their first and main educators. This educational task is of such paramount importance that it would be hardly possible to replace its possible lack"4. John Paul II speaks even stronger about the right of the parents to bring up their children: "the right and duty of the parents to bring up is something significant and is as such connected with the transmission of life itself; it is primary and has the priority over educational tasks of other people because of the unique character of love relationship uniting parents and children; it excludes substitution and is inalienable, therefore it cannot be entirely handed over to others or usurped by others" 5 .

In The Family Rights Charter the Catholic Church, once more, has claimed this right: "Parents, as they have given life to children, have the primary, inalienable right

2 The UN General Assembly, The Declaration of Child Rights, p. 244-247.

3 The UN General Assembly, Pacts of Human Rights, p. 198-220.

4 Vatican Council II, The Declaration of Christian Upbringing, no. 3.

5 John Paul II, Familiaris consortio, no. 36. 
and the priority in bringing up children, and therefore they have to be recognized as first and main educators" 6 .

The role of parents in the process of shaping the child's personality has been distinctly expressed by A. Kępiński: "The emotional bond with the mother is a matrix on which further emotional connections with the environment are shaped. (...) The part of the surrounding world to which a man is bound most, and so the most intense part, is firstly the mother, then both parents and the whole family"7. Therefore one must not separate a child from his family, because it would result in cutting him off from his roots. In conclusion, it should be said that, according to common sense and the natural law of human development, the family should be given the priority in bringing up children.

\section{The Need for, and Ways of Parent Pedagogization with Regard to Raising Children}

The prevailing conviction is that parents are able to bring up children by the sheer fact of being parents. Hence, they do not need any other sources of knowledge because they themselves know best what their child needs and how to deal with him. It is true that the parents are able to bring up the family as a consequence of close and unique emotional contact with their child and by creating the environment so essential for upbringing. But it is also true that the tasks of the parents require incomparably more preparation than the role of educators in strict terms. Parents should realize the long-lasting influence they have on their child. Upbringing mistakes made by them result in educational defects of children, which are later difficult or impossible to repair. Though parenthood, in its deepest meaning, cannot be learned even from the best books, yet knowledge, reflection and a conscious good will to fulfill this vocation in the best way possible, are necessary for every parent.

6 The Apostle Capital, The Family Rights Charter, article 5. E. Osewska, Religious Education from the Perspective of Central and Eastern Europe, in: Toward Mutual Groud. Pluralism, Religious Education and Diversity in Irish Schools, eds. G. Byrne, P. Kieran, Dublin 2013, p. 133-143; E. Osewska, The Current Situation of Education and Continuing Professional Development of RE Teachers in Poland in the Context of the Social Challenges, "The Person and the Challenges" 2 (2012) Nr 2, p. 123-131.

7 A. Kępiński, Of the Psychopatology of Sexual Life, Warsaw 1973, p. 27 and 63. 
Erich Fromm wrote: "The whole human life is nothing but the process of self-

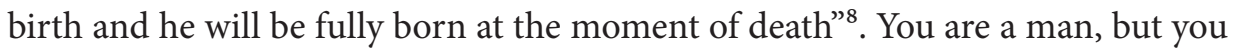
also constantly become a man'. The process of human development is not finished with the contraction of marriage and production of offspring. It goes on, and it is not as autonomous as that dependent on educational incentives. It remains an opportunity and possibility, and it depends on whether persons will recognize and undertake this opportunity and possibility, and thus whether they will get involved in their own development. Such involvement becomes obvious when an individual continues his education (e.g. at evening courses) or even simply when somebody takes a driving license course or foreign language lessons. Human development reaches into many directions and many areas, and is a life-long process. If it is to be harmonious, it should take into consideration a human person's transcendental destination, as well as his attitude towards society, and consequently, to the higher and broader constitutions into which the human person is, somehow by matter of course, composed ${ }^{10}$.

The truth about life, understood as a great gift, should be deeply rooted in the consciousness of the parents. Life is given to us, but it is also assigned to us, hence, the need of constant concern over self-development, in order to be able to influence the offspring properly and effectively.

An adult, shaped by educating process started in childhood, during his life finds himself at particular stages of his development. This development may progress, remain at a certain level or regress. There are many factors which stimulate this inner development. They are important for constant maintenance of the will, to acquire new information or skills, and also for the permanent undertaking of the process of self-improvement. Only in this way, the life wisdom and the inner harmony of the parent-educator can be created. The child often emulates his parents. Therefore, being familiar with psychology of parenthood and childhood is vital in the process of upbringing. One cannot raise children without possessing adequate knowledge about them. Thus the requirements for pedagogization stem from the needs of the child as the one who is being brought up in the family.

8 E. Faure, To Learn in Order to Be, Warsaw 1978, p. 301.

9 Compare W. Stróżewski, Of Becoming a Man, in: F. Adamski, Man-Education-Culture, Cracow 1993, p. 52-58.

10 J. Majka, Christian Upbringing as Personal Upbringing, in: F. Adamski (ed.), Upbringing in Christian Family, Cracow 1984, p. 51. 
The knowledge of the child is crucial for bringing him or her up properly. This knowledge, though, is not easy to acquire. The child is a complex creature and needs to be studied with regard to different aspects, and with the help of numerous disciplines that constitute the knowledge about the child. Here, I will restrict ourselves only to some of them. In my opinion, the most important to our theme is family psychology, which comprises child psychology and parent psychology. What is also very helpful is the study of biology, particularly familiarity with the study of heredity (that is formal genetics), and the study of the educational environment as well as pedagogy. As far as other scientific fields such as medicine, hygiene or house economy, we refer the reader to specialists, popular books and brochures in these fields which are easy to obtain.

Elżbieta Sujak in her article Child - an Unknown Creature ${ }^{11}$ discusses the question of the constant contact with the child. This problem, being the basis of the upbringing process, is faced by many parents. The difficulty under discussion is quite significant when it comes to understanding the child's experiences in different life situations. It is not easy for the parents to understand their own children, and, consequently, to influence them properly as educators. The reasons behind this situation have been discussed by Sujak. He enlists first a number of existing myths connected with the concept of childhood such as "childhood innocence", "childhood cunning", and also "happy childhood". These myths are eternal, but at the same time, we have to be conscious of the fact that we create them ourselves. Parents should constantly rationalize these myths.

Between the world of adults and the world of the child there is a border similar to a "rock precipice"12. Only exceptional efforts and pedagogical abilities can allow to cross this border. It is not done away with by the fact that parents themselves used to be children. Their memories do not store much from this period. The inaccuracy and fragmentation of the memory material saved as recollections make them a very rickety footbridge between parents and children. The poor quality of childhood memories comes from the fact that an individual stores in his memory recollections that are ready to be called to mind and only the events experienced in the state of his full consciousness. These are rather scarce in childhood.

Parents tend to look for the causes of educational difficulties in the parent-child relationship outside of themselves, and tend to find them mainly in the child. The process of the parents' learning about the child is usually accompanied by strong

\footnotetext{
11 Sign 7-8 (1968), p. 927-937.

12 Ditto, p. 928.
} 
emotional element which distorts this process. What can often be observed is the so-called projection and blinding. Projection occurs when the parents try to realize their ambitions in bringing up children. Blinding occurs when they do not perceive the features which are inconsistent with their wishes or fears or with the ideal image of the child created by their imagination.

Children are often misunderstood by the parents who tend to ascribe to the motives analogous to those of adults, or they set up requirements beyond the child's possibilities. Children, on the other hand, are not able to communicate their experiences to their parents in the way the latter expect it.

Presenting the above problems of the parent-child relationship, I do not wish to state that this contact and understanding are impossible. I just want to stress the fact and the need for the constant parents' care for the future of the child. I also emphasize the necessity of efforts that are needed to achieve the best results of the educational activity.

\section{New Education as the Challenge to Parents}

'New education' (I will not attempt the analysis of this complex term, since it would be outside the scope of this paper) is undoubtedly a challenge to today's parents. The aim of educational process is to prepare an individual for different tasks in constantly changing circumstances and conditions of life. Let us focus only on the two aspects of the new - or, properly thought out - education, namely on the facts that it requires knowledge, but at the same time is a kind of art.

Family is an open structure, so it brings up the child not just for itself, but prepares him to exist - in the future - in other communities. Thus, it has to take into consideration their needs and demands for social and cultural values. Even though the family will not supply them ready-made (as this exceeds its possibilities), it still has to lay some foundations for them within the child. This already calls for some professional knowledge in the field of upbringing.

It is important for parents, as educators, to face at least basic educational questions, the elementary problems of education, to realize that such questions and problems exist, and in this way, to evoke, in themselves, some kind of educational reflection. One does not have to be a master in performing the duties and his responsibilities imposed to him, but certainly one must not be totally uninitiated.

As a matter of fact, there is no measure or recipe for bringing up a human being. An individual is a complex and complicated creature, revealing such richness of mental and spiritual nature, and so many possibilities of development, that it 
would be dangerously arrogant to claim that we have a ready recipe to shape one's personality.

Besides, even in the family, each person is different, each child is a distinct individual, so it is not possible to apply the same measure and the same educational methods to everybody. It is also difficult to talk about a "single" pedagogy; it would be better to assume that there are as many kinds of pedagogy as there are people in want of upbringing. The process under discussion is different for every child, it is peculiar because of the differences of one's mental features and inner environment.

Hence, we can risk the statement that upbringing is, by its nature, an art. It is a function of the educator's personality, which brings together all (sometimes contradictory) elements of the educational situation and influences other, still forming personalities, each of which has its own specific and characteristic features. It is not possible to deal with all the children in the same way. The selection of the methods and means adequate for particular conditions of development of each child and their particular mental properties, bears the mark of the educational level and characteristic features of the educator and his methods.

However, while one is not an artist, and thus he cannot learn a 'ready' art once and for all, similarly one cannot learn upbringing, since it is a process that undergoes constant development. There are, however, certain inner and outer conditions necessary for its progress, and their knowledge is vital for the educator. These also include some general rules and a set of methods whose knowledge cannot be left out or disregarded in upbringing. Therefore, while talking about the art of upbringing, we must not forget that it is also a skill.

As soon as an individual finds himself immersed in diverse social relations and different cultural values, the process of his upbringing becomes a complicated task, requiring for thorough preparation, knowledge and skills of the educators. Parents cannot be excluded from this, as they lay the foundations for the development of the child's personality, prepare him for certain duties and roles in today's complex reality.

The whole of families in a given society is made up of families of different levels and efficiency in realizing the social, protective, educational, cultural, religious and procreational functions ${ }^{13}$. Taking the competence, knowledge and skills as

13 Compare P. Poręba, Parent Pedagogization, "Studia Warmińskie" 6 (1969), p. 464-466. 
the main criteria for the satisfactory fulfillment of marital and parental duties, the following types of parents can be distinguished ${ }^{14}$ :

- parents who know their parental rights and duties, properly prepared, who are equipped with the appropriate knowledge, competence, skills, who have developed positive pro-family and parental attitudes. They also know their limitations with regard to new events, situations, and problems, but they are able to use professional literature and, in fact, they neither need nor look for assistance from the professional people or institutions;

- parents who possess a proper level of knowledge, competence, skills and attitudes, but are not sure of their decisions, the choice of educational methods or they lack time and they would rather follow the guidance of the professionals; they themselves look for such assistance and help;

- parents who do not have the proper knowledge, skills and competence but they display fully developed positive pro-family and parental attitudes and they consciously look for help and guidance in solving family and education problems;

- parents who do not have appropriate skills, knowledge, educational competence, the ability to make decisions, who lack empathy, cannot solve conflicts and they do not look for the help of professionals, even though they are characterized by positive pro-family and parental attitudes;

- parents who not only lack appropriate skills and the competence of educating and of interpersonal communication, but also display serious inner conflicts, personality disintegration and lack of adaptation, and even criminal patterns or behavior. At the same time, they fail to perceive the situation as requiring change, help, guidance, therapy or "resocialization".

The above categorization of parents does not exhaust the problem and probably could be broadened. It constitutes just a basis for outlining the question of help and psychological-pedagogical assistance for the family. It demonstrates clearly that we can talk about a group of people who need help and support, and about a group of people who should be actively sought out and motivated to acquire the knowledge, skills and competence, as well as to change their attitudes and behaviors. This very fact imposes on advisory institutions and professionals the necessity to prepare themselves for work with people looking for help or those who are forced, e.g. by a decision of a legal or educational institution, to receive advice, support or therapy.

14 Compare K. Ostrowska, Psychologically-Pedagogical Help for Family, in: G. Olszewska-Baka, L. Pytka (eds.), Help for Family, Białystok 1999, p. 101-110. 
In each of these cases, the forms of professional assistance will be different, even though the ultimate aim is the same - e.g. improving the educational situation of the family. In the contemporary world, on one hand, families are left to their own resources with the belief that family life is a private matter, but on the other hand the family is the primary group that is expected to satisfy the marital, social, moral and spiritual needs of a given society ${ }^{15}$.

Parents, exposed to the pressure of new technology, the pace of work and social changes, want to secure their financial position and the realization of many needs by taking up more duties related to their career. This results in the lack of time, and physical and mental absence at home. This can cause emotional disorders in the children, manifested through the tendency to depression, anger, excitability, disobedience, arrogance, and even crime. Other significant symptoms are anorexia, bulimia, abusing tobacco, alcohol and drugs. The constant rush and lack of time also have a negative impact on interpersonal relationships of the adults. There is no room for observing behavior and emotions or for conversation. As a result, we can observe lack of empathy or communication skills, which can lead to many tensions and conflicts.

\section{Conclusion}

Children upbringing is currently the only field for which hardly anybody prepares the parents. Their conscious and intentional endeavors often contradict with their behavior and lifestyle, which cannot bring satisfactory effects.

Among the forms of help in family education nowadays, the so-called parent pedagogization takes the lead. The term "parent pedagogization" usually covers all those forms of work whose purpose is to acquaint parents with educational questions, and assist them in solving difficulties. It seems that we can find the justification for the mentioned action in the changed form of the educational process. As the result of changes in the contemporary family structure, the upbringing in the family has

15 J. Stala, Familienkatechese in Polen um die Jahrhundertwende. Probleme und Herausforderungen, Tarnów 2008; J. Stala, Ręce mego ojca i usta mojej matki powiedziały mi najwięcej o Bogu. Biskupa Piotra Bednarczyka ujęcie katechezy rodzinnej, Tarnów 2011; Religious Education / Catechesis in the Family. A European Perspective, eds. E. Osewska, J. Stala, Warszawa 2010; Nauki o rodzinie w służbie rodziny, ed. J. Stala, Kraków 2014. 
emerged as a distinct activity, requiring special qualifications and time, for which today's parents are not prepared.

Hence, there emerges the need to organize proper guidance and pedagogization of spouses and parents. This process should include not only information, but, first and foremost, it should help the couples to shape their marital and parental attitudes properly.

\section{Bibliography}

Faure E., To Learn in Order to Be, Warsaw 1978.

John Paul II, Familiaris Consortio, Vatican 1981.

Kępiński A., Of the Psychopatology of Sexual Life, Warsaw 1973.

Majka J., Christian Upbringing as Personal Upbringing, in: Adamski F. (ed.), Upbringing in Christian Family, Cracow 1984, p. 33-52.

Nauki o rodzinie w stużbie rodziny, ed. J. Stala, Kraków 2014.

Osewska E., Religious Education from the Perspective of Central and Eastern Europe, in: Toward Mutual Groud. Pluralism, Religious Education and Diversity in Irish Schools, ed. G. Byrne, P. Kieran, Dublin 2013, p. 133-143.

Osewska E., The Current Situation of Education and Continuing Professional Development of RE Teachers in Poland in the Context of the Social Challenges, "The Person and the Challenges" 2 (2012) Nr 2, p. 123-131.

Ostrowska K., Psychologically-Pedagogical Help for Family, in: G. Olszewska-Baka, L. Pytka (eds.), Help for Family, Białystok 1999, p. 101-110.

Poręba P., Parent Pedagogization, "Studia Warmińskie” 6 (1969), p. 423-487.

Religious Education / Catechesis in the Family. A European Perspective, eds. E. Osewska, J. Stala, Warszawa 2010.

Stala J., Familienkatechese in Polen um die Jahrhundertwende. Probleme und Herausforderungen, Tarnów 2008.

Stala J., Ręce mego ojca i usta mojej matki powiedziaty mi najwięcej o Bogu. Biskupa Piotra Bednarczyka ujęcie katechezy rodzinnej, Tarnów 2011.

Stróżewski W., OfBecoming a Man, in: F. Adamski, Man-Education-Culture, Cracow 1993, p. 52-58.

The UN General Assembly, Common Declaration of Human Rights, in: Machowski J., Work of Man, Warsaw 1968, p. 191-197.

The UN General Assembly, The Declaration of Rights of the Child http://www.cirp.org/library/ ethics/UN-declaration/ (02.03.2015)

The UN General Assembly, Pacts of Human Rights, http://www.un.org/rights/ (02.03.2015). 
Vatican Council II, The Declaration of Christian Upbringing. http://www.vatican.va/archive/ hist_councils/ii_vatican_council/documents/vat-ii_decl_19651028_gravissimumeducationis_en.html (02.03.2015). 